\title{
Climate of opportunity
}

\section{With the shift of power in the US Congress comes an chance to re-engage in the debate over climate change. But the process will not be simple, says our new columnist David Goldston.}

$T$ he 110th Congress convened in Washington DC on 4 January, with the Democrats in control of both chambers for the first time in a dozen years. The banging of the gavel by the new Speaker of the House, Nancy Pelosi, was in effect the starting gun for what is likely to be two years of political strife, as both Democrats and Republicans race towards the 2008 congressional and presidential elections.

The political and legislative manoeuvring is likely to be especially fierce because no one knows who holds the upper hand. It is true that technically the Democrats have the advantage. But, given their tenuous, two-seat majority in the Senate and the ideological diversity of their caucus in the House of Representatives, to what extent will they really be able to control the congressional agenda? Washington feels especially unsettled now, with a weakened president, an untested Congress, and a 2008 presidential primary process that is up for grabs in both parties.

But none of the manoeuvring is likely to yield significant changes for either the conduct or application of science in the near term.

To take one obvious example, the budget outlook for science is not likely to be appreciably different - the two parties support similar funding levels for research. (I'll have more to say on that next month, when President Bush releases his proposed budget for the next fiscal year.)

And the debate over embryonic stem-cell research is likely to be a rerun. The House has already passed a bill, identical to one passed last year in both chambers, easing the federal prohibition on research using new stem-cell lines. The Senate is likely to take up this or an amended version - but either way, the president is expected to veto it, just as he did its predecessor. The exercise will have more to do with making sure voters know where individual politicians stand on the issue than with changing stem-cell policy.

But Democratic control of Congress is likely to jump-start one genuine debate - that on policies to address climate change. Republican leaders had shut off all such debate in the House, and policy discussions have long been idling in the Senate, where the loudest voice was Senator James Inhofe (Republican, Oklahoma), with his show

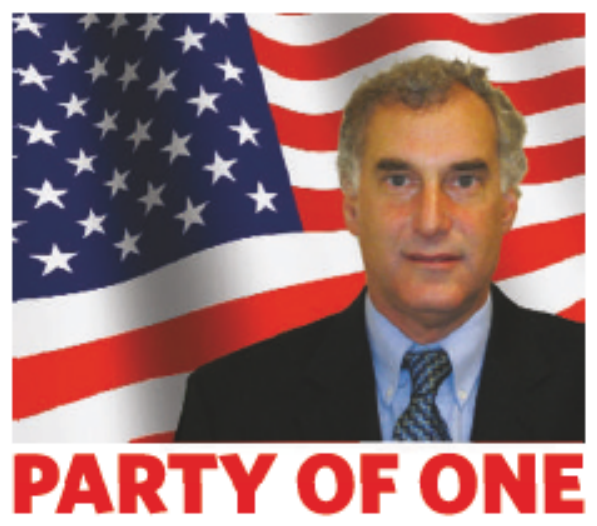

trials to try to prove that global warming is a 'hoax.' Now, bipartisan efforts are under way to cobble together a regulatory bill that could make a dent in US greenhouse-gas emissions.

Such a task will not be easy. First, the key Senate players - Democrats Joe Lieberman of Connecticut, Barbara Boxer of California and Jeff Bingaman of New Mexico, and Republicans John McCain of Arizona and Pete Domenici of New Mexico - will have to figure out how to work together after years of offering up competing approaches.

Then they will have to decide if they want to compromise enough with the rest of their colleagues for the Senate to pass a bill, or whether they would be satisfied with building momentum for a more ambitious measure. The prospect of real action on climate change might actually make it harder to garner votes for a far-reaching bill. In past Congresses, some senators were willing to vote for a greenhouse-gas bill put forth by Senators MoCain and Lieberman; such a vote signalled that they wanted to do something about climate change, but they didn't have to worry about the details because the bill clearly wasn't going anywhere with the Republicans in control of Congress.

Environmental groups are now in the process of making similar strategic calculations. Should they attack any measure that doesn'tplace a strict economy-wide cap on greenhouse-gas emissions, for fear that half-steps will sap political momentum? Or would such a move alienate their political allies as too absolutist, thereby slowing momentum?
Similarly, industry groups, which are all over the map on whether and how to regulate greenhouse-gas emissions, will have to decide where to draw their battle lines. They will no doubt face pressure not to give ground from Republican leaders, who, after all, still control the White House and may be back in power in Congress in two years.

And House Democrats have yet to embrace climate change as part of their agenda, fearing that it will fracture their fragile caucus, which features a greater number of politically vulnerable Democrats from oil- and coalproducing regions than the Senate.

But the biggest wild card of all on the climate issue - and the one that makes it so hard for any of the players to figure out how to play their hands - is the public. Polls generally show that the American public thinks climate change is real and wants action to counter it. But the depth of public understanding and support for action are far from clear.

Green politicians and groups have generally taken the line that environmental improvements can be made without personal sacrifice. Al Gore's movie An Inconvenient Truth seems to go out of its way to play down the difficulties in controlling climate change, to ensure that no one leaves the film thinking that taking action would be futile.

A serious debate in the Senate should increase the media and public focus on what is really at stake in regulating greenhouse gases. That might allow pollsters to get a firmer sense of where the American public stands on policy options - a prerequisite for any serious action on dimate change. Given that several Congresses usually have to work on major legislation for years before it becomes law, engaging the public may be the most important result of any debate over the next two years. And the complexity of that policy discussion will make the previous congressional debate over whether climate change even exists seem like child's play. David Goldston is a visiting lecturer and practitioner-in-residence at Princeton University's Woodrow Wilson School of Public and International Affairs. He served as chief of staff for the House Committee on Science between 2001 and 2006. See Editorial, page 230 